\title{
Eksplorasi Etnomatematika pada Bangunan Tradisional Uma Lengge
}

\author{
Andi Hasliyati Ike Safitri ${ }^{1}$, Ilham Dwi Novaldin ${ }^{2}$, M. Gunawan Supiarmo ${ }^{3}$ \\ 1,2,3 Program Magister Pendidikan Matematika, Fakultas Tarbiyah dan Ilmu Keguruan, UIN Maulana Malik Ibrahim Malang \\ Jl. Tarbiyah, Dinoyo, Kec. Lowokwaru, Kota Malang, Jawa Timur 65149 \\ ikesafitri157@gmail.com
}

\begin{abstract}
This study aims to explore ethnomathematics in Uma Lengge, as an effort to facilitate the process of learning mathematics with a cultural approach, especially in recognizing the spatial structure of Uma Lengge traditional buildings. A learning process that occurs through cultural activities by community groups, namely the process of calculating or analyzing data. The type of research used is exploratory-descriptive research. The research flow consists of documenting everything related to the traditional Uma Lengge building, conducting interviews with respondents, and obtaining research results and conclusions. The results showed that the measurement methods used by the traditional Bima community were very diverse, starting from using the fingers, sakimi (fist), measuring sasingku (one fathom) which was carried out using the elbow, and at a size of more than one meter, it was done by extending one hand and fold the other hand in half. In addition, in the design of the Uma Lengge building there is a geometric concept of flat wake and space. The concept of a flat shape in the Uma Lengge building includes the concept and principle of a triangle in the Czech, a square pattern in a lante, and a rectangular pattern in a kabu tadancai. Furthermore, the concepts of spatial structure in Uma Lengge, namely the concept and principle of a triangular prism on the roof, the concept and principle of the cube in the ro woha, the concept and principle of the beam in nggore, and the concept of pyramid frustum on the lamp.
\end{abstract}

Keywords: Ethnomathematics, Traditional Buildings, Uma Lengge

\begin{abstract}
Abstrak
Penelitian ini bertujuan untuk melakukan eksplorasi terhadap etnomatematika pada Uma Lengge, sebagai upaya memudahkan proses pembelajaran matematika dengan pendekatan budaya, khususnya dalam mengenal bangun ruang pada bangunan tradisional Uma Lengge. Suatu proses belajar yang terjadi lewat adanya aktivitas secara kultural oleh kelompok masyarakat, yaitu proses menghitung ataupun menganalisis data. Adapun jenis penelitian yang digunakan adalah penelitian eksploratif-deskriptif. Adapun alur penelitian terdiri atas pendokumentasian segala hal yang terkait dengan bangunan tradisional Uma Lengge, melakukan wawancara terhadap responden, dan memperoleh hasil serta kesimpulan penelitian. Hasil penelitian menunjukkan bahwa metode pengukuran yang digunakan masyarakat tradisional Bima sangat beragam yang dimulai dari menggunakan jari, sakimi (kepalan tangan), pengukuran sasingku (satu depa) yang dilakukan menggunakan siku, dan pada ukuran yang lebih satu meter dilakukan dengan melentangkan satu bagian tangan dan melipat setengah bagian tangan yang lain. Selain itu, pada rancang bangunan Uma Lengge terdapat konsep geometri bangun datar dan bangun ruang. Adapun konsep bangun datar pada bangunan Uma Lengge, antara lain konsep dan prinsip segitiga pada ceko, pola persegi pada lante, dan pola persegi panjang pada kabu tadancai. Selanjutnya konsep-konsep bangun ruang pada Uma Lengge, yaitu konsep dan prinsip prisma segitiga pada atap, konsep dan prinsip kubus pada ro woha, konsep dan prinsip balok dalam nggore, dan konsep frustum piramida pada pelampu
\end{abstract}

Kata kunci: Etnomatematika, Bangunan Tradisional, Uma Lengge

Copyright (c) 2021 Andi Hasliyati Ike Safitri, Ilham Dwi Novaldin, M. Gunawan Supiarmo

$\triangle$ Corresponding author: Gunawan Supiarmo

Email address: gunawansupiarmo@gmail.com (Jl. Tarbiyah, Dinoyo, Kec. Lowokwaru, Kota Malang)

Received 11 July 2021, Accepted 26 November 2021, Published 30 November 2021

\section{PENDAHULUAN}

Matematika merupakan ilmu pengetahuan yang memiliki sumbangsih besar terhadap kemajuan teknologi modern abad 21 (Mulbar, 2012). Pembelajaran matematika juga merupakan bagian penting pendidikan yang berperan mengembangkan proses berpikir siswa dalam menghadapi masalah dan melatih persiapan berpikir tersebut untuk masa depan siswa. Pemahaman matematis menjadi satu kompetensi dasar dalam mempelajari matematika, yaitu kemampuan menyerap materi, mengingat 
konsep dan rumus matematika, serta mampu menerapkannya dalam kasus serupa, dengan memperkirakan kebenaran suatu pernyataan, dan menggunakan rumus yang tepat dalam teorema penyelesaian masalah (Dewi Murniati dkk., 2013).

Pembelajaran matematika hendaknya dikaitkan dengan realitas kehidupan sehari-hari, karena matematika telah membudaya pada kehidupan siswa di masyarakat (Putri, 2017; Sandhi dkk., 2018). Hal ini dikarenakan pembelajaran yang didalamnya terjadi interaksi sosial dan budaya merupakan cerminan pembelajaran matematika yang baik (Elly Susanti dkk., 2020; Sudirman dkk., 2017). Adapun pembelajaran yang orientasinya berkaitan dengan matematika dan budaya disebut sebagai etnomatematika (Asnawati dkk., 2015; Putri, 2017).

Etnomatematika pertama kali diperkenalkan oleh seorang matematikawan terkenal yang berasal dari Brazil bernama D'Ambrosio pada tahun 1985. Etnomatematika disebut sebagai ilmu pengetahuan melalui budaya sebagai titik awal membangun dan menghubungkan pemahaman siswa dari matematika informal menuju matematika formal (D Herawaty dkk., 2018; Richardo, 2017). Perkembangan etnomatematika melalui budaya membuat masyarakat tidak menyadari adanya etnomatematika, karena dinilai sederhana jika dibandingkan dengan matematika formal di sekolah (Samo, 2017; Sandhi dkk., 2018).

Etnomatematika didefinisikan sebagai aktivitas matematika yang dilakukan kelompok budaya tertentu dalam masyarakat (Ulum dkk., 2018). Kemajuan ilmu pengetahuan memberikan ruang terhadap pengaplikasian etnomatematika di sekolah guna menanggulangi masalah kompleks pada praktik pembelajaran matematika, sehingga penerapannya mulai berkembang pesat dalam pendidikan khususnya di Indonesia (Putri, 2017; Widada dkk., 2019). Selain itu, etnomatematika lahir melalui kebiasaan masyarakat tradisional salah satunya dalam bentuk bangunan tradisional berupa rumah adat (Jayanti \& Puspasari, 2020; Sudirman dkk., 2017).

Beberapa penelitian terkait eksplorasi etnomatematika pada bangunan tradisional khususnya rumah adat telah dilakukan, antara lain penelitian Yuningsih dkk., (2021) mengenai eksplorasi etnomatematika pada rancang bangunan rumah adat Lengkong. Penelitian Funan dkk., (2019) yang membahas eksplorasi konsep-konsep matematika materi geometri yang terdapat pada bangunan tradisional Uem Ie'u. Penelitian Darmayasa, Wahyudin, (2018) tentang penggunaan konsep matematika pada struktur bangunan Saka Roras desa Songan. Penelitian Sulistyani dkk., (2019) dengan melakukan eksplorasi etnomatematika terhadap rumah adat Joglo di Tulungagung. Penelitian Suharta, (2017) mengeksplorasi konsep matematika pada rumah tradisional Bali. Penelitian Tlonaen \& Deda, (2021) mengenai eksplorasi etnomatematika pada rumah tradisional Ume Kbubu. Adapun pada penelitian ini, kajian etnomatematika terfokuskan pada rumah adat suku Mbojo yaitu Uma Lengge.

Uma Lengge adalah rumah adat yang berada di Kecamatan Wawo Bima Provinsi Nusa Tenggara Barat. Uma Lengge juga merupakan bangunan tradisional yang berfungsi sebagai lumbung padi masyarakat setempat, dan masih dapat ditemukan pada daerah-daerah pelosok Bima sampai sekarang. Lantai Uma Lengge biasanya terbuat dari bambu dengan dinding dari anyaman daun pohon 
lontar dan arin yang tersusun dengan perpaduan warna-warni yang merupakan hasil pewarnaan dari bahan alami. Kemudian atap Uma Lengge terbuat dari alang-alang atau bambu sirap, serta disekitar rumah biasanya dibuatkan gantungan dari kayu atau bambu sebagai tempat menaruh alat dan perkakas rumahan, dan sebagai tempat penjemuran bahan makanan misalnya ubi, gandum, jagung dan lain-lain.

Uma Lengge memiliki tiga ruangan, yaitu ruang ro awa (ruangan bawah), ro woha (ruangan tengah) dan ro ese (ruangan atas). Ro awa merupakan ruangan terbuka terbuat dari bambu yang biasa digunakan sebagai tempat hewan ternak seperti ayam dan kambing. Ro woha merupakan ruangan terbuka yang tersusun dari empat tiang utama yang biasanya dijadikan sebagai tempat beristirahat dan menerima tamu. Adapun ro ese adalah ruangan utama berbentuk prisma segitiga yang berfungsi sebagai tempat menyimpan persediaan makanan.

Pada proses pembuatan Uma Lengge, masyarakat Bima menggunakan metode pengukuran secara turun-temurun. Hal ini membuktikan bahwa rancang bangunan Uma Lengge tidak terlepas dari aktivitas matematika yang dilakukan masyarakat tradisional Bima. Aktivitas matematika tersebut berupa metode pengukuran secara tradisional terkait komponen-kompenen yang membangun rumah adat tersebut. Selain itu, Ume Lengge memiliki arsitektur bangunan yang sangat merepresentasikan bentuk geometris seperti kerucut, prisma, segitiga, limas, segiempat dan lain-lain.

Berdasarkan uraian di atas, maka pada penelitian ini akan dilakukan eksplorasi terkait konsepkonsep matematika pada rancang bangunan Uma Lengge. Hal ini juga didukung oleh fakta bahwa belum adanya penelitian tentang eksplorasi etnomatematika pada rumah adat suku Bima tersebut. Oleh karena itu, peneliti akan melakukan penelitian yang berjudul "Eksplorasi Etnomatematika pada Bangunan Tradisional Uma Lengge".

\section{METODE}

Jenis penelitian ini menggunakan eksploratif-deskriptif yang bertujuan untuk mengeksplorasi keberadaan konsep matematika pada komponen dan arsitektur bangunan tradisonal Uma Lengge. Kemudian mendeskripsikan konsep-konsep geometris yang terdapat pada Uma Lengge. Daerah penelitian ditentukan di desa Maria, Kecamatan Wawo yang dipilih karena merupakan pengembangan dari desa budaya dan wisata serta hingga kini masih dijumpai keberadaan bangunan tradisional Uma Lengge di daerah tersebut.

Responden dalam penelitian ini ditentukan dengan metode purposive sampling. Responden yang dipilih adalah penjaga, para budayawan dan pengrajin sebagai pembuat bangunan tradisoanal Uma Lengge. Peneliti menggali informasi melalui observasi, berupa pengamatan langsung pada bangunan tradisional Uma Lengge, kepustakaan ialah menelaah referensi tertulis yang menjelaskan terkait bangunan tradisonal Uma Lengge, dan wawancara dengan beberapa tokoh atau warga setempat yang memahami lebih dalam terkait objek penelitian. Penentuan responden dilakukan dengan pertimbangan bahwa responden harus mengetahui sejarah dan memahami tentang konstruksi bangunan Uma Lengge. Alur penelitian ini, yaitu pendokumentasian segala hal yang terkait dengan bangunan tradisional Uma 
Lengge, melakukan wawancara terhadap responden untuk menggali informasi, dan memperoleh hasil serta kesimpulan penelitian. Teknik analisis data yang digunakan, antara lain ialah reduksi data yaitu suatu bentuk analisis yang lebih memperdalam atau mempertajam data dengan menggolongkan data tersebut. Selanjutnya penyajian data, peneliti memaparkan data penelitian yang direduksi dan menguraikan rumusan masalah sehingga memperoleh data yang akurat terkait eksplorasi etnomatematika pada Uma Lengge. Adapun langkah terakhir ialah verifikasi, dimana peneliti melakukan analisis dan pembahasan agar penelitian yang dilakukan valid sehingga memperoleh kesimpulan untuk menjawab rumusan masalah penelitian.

\section{HASIL DAN DISKUSI}

Uma Lengge merupakan bangunan tradisional dan bagian dari budaya warisan leluhur suku Mbojo. Uma Lengge berfungsi sebagai lumbung padi masyarakat setempat yang masih dapat ditemukan pada daerah-daerah pelosok Bima. Pada proses pembuatan Uma Lengge tidak terlepas dari aktivitas matematika masyarakat tradisional Bima. Aktivitas matematika tersebut berupa metode pengukuran secara tradisional terkait komponen-kompenen yang membangun Uma Lengge.

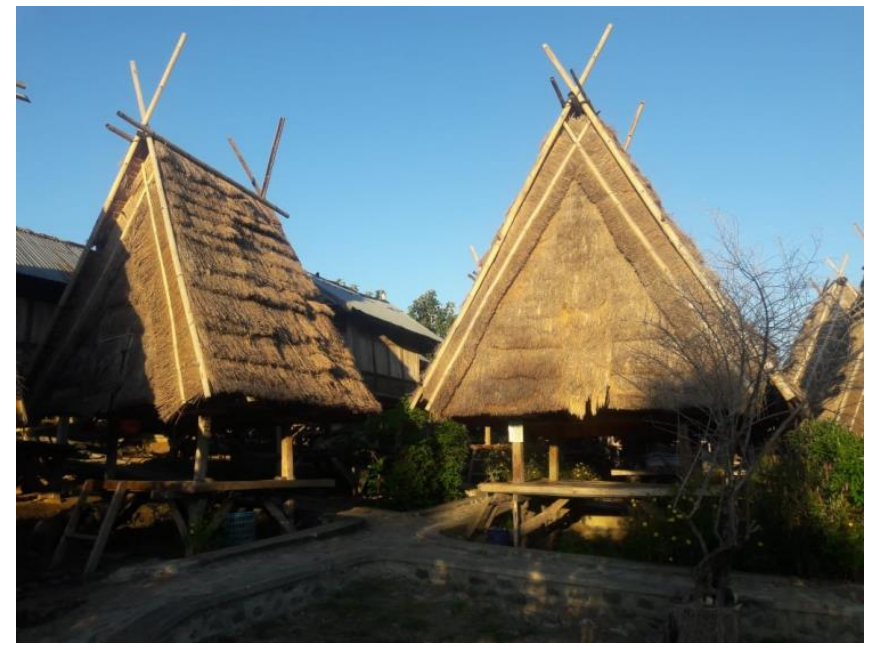

Gambar 1. Ume Lengge

Secara umum struktur bangunan Uma Lengge juga memiliki beberapa arsitektur geometris. Pintu Uma Lengge berbentuk persegi panjang, lantai bangunan (lante awa, woha dan ese) berbentuk kubus, dan permukaan lante pada masing-masing ruangan tersebut berbentuk persegi. Bagian atap bangunan tradisional ini memiliki bentuk prismasegitiga, sedangkan pali peto (pelapis antara tiang dan batu) menggunakan balok dengan bentuk persegi. Selain itu, terdapat ceko (sepasang penyiku) pada Uma Lengge membentuk pola segitiga siku-siku, dan nggore (balok penyangka tempat duduk lante ro $a w a)$ yang berbentuk balok.

Berdasarkan uraian di atas, dapat diketahui bahwa pada bangunan Uma Lengge terdapat aktivitas matematika berupa metode pengukuran tradisional yang dilakukan masyarakat Bima. Selain 
itu, Uma Lengge juga memiliki beberapa arsitektur geometris pada komponen-komponen bangunannya. Hal ini akan diungkap lebih mendalam pada deskripsi berikut:

\section{Aktivitas Matematika pada Rancang Bangun Ume Lengge}

Penulis melakukan penelitian dan menemukan adanya perbandingan ukuran di beberapa bangunan yang ada. Ternyata pada beberapa bangunan ini memiliki selisih sepersekian meter. Hal ini dipengaruhi oleh cara pengrajin pada zamannya dalam menghitung dan menentukan ukuran potongan maupun bagian-bagian bangunan tradisional Uma Lengge. Adapun penentuan ukuran ruangan didasarkan pada proses dan cara menghitung tradisional oleh masyarakat Bima. Pada zaman dahulu mereka tidak mengenal alat ukur meteran, melainkan menfungsikan bagian-bagian dari tubuh mereka.

Metode pengukuran yang digunakan masyarakat tradisional Bima sangat beragam. Dari ukuran yang paling terkecil atau terpendek hingga terbesar atau terpanjang. Ukuran terkecil dimulai dari menggunakan jari yang terbagi menjadi beberapa bentuk ukuran, antara lain sajari (satu jari dengan ukuran kurang lebih 1 sampai $2 \mathrm{~cm}$ ), dua jari (dua jari), tolu jari (tiga jari), upa jari (empat jari), dan satongko (lima jari). Metode pengukuran menggunakan jari dilakukan pada proses pembuatan pali peto (potongan kayu yang dijadikan sebagai alas antara batu dengan ke empat tiang utama bangunan), dan pada proses pembuatan wole (stik pasak).

Metode pengukuran tradisional masyarakat Bima juga menggunakan patokan kepalan tangan. Ukuran sekepal tangan dalam bahasa Bima disebut sakimi, biasanya ini untuk mengukur alat atau perkakas tradisional dengan cara digenggam, contohnya pada ukuran pegangan parang, keris, pisau dan lain-lain. Adapun untuk mengukur alat tradisional yang memiliki ukuran relatif pendek seperti tembilang menggunakan sacaka (ukuran jengkal). Sacaka terbagi menjadi dua, yaitu sacaka biasa (sejengkal penuh) dan sacaka turu (kurang sejengkal, ini menggunakan telunjung dan ibu jari).

Selanjutnya, metode pengukuran sasingku (satu depa) yang dilakukan menggunakan siku. Teknik pengukuran sasingku terbagi menjadi dua, antara lain sasingku kimi (satu depa dengan cara jari tangan dikepal) dan sasingku dala (satu depa dengan cara jari tangan dibuka). Sasingku pada proses pembuatan Uma Lengge digunakan saat pembuatan atau pemilihan batu sebagai pali (pondasi dasar). Selain itu, sasingku juga digunakan ketika membuat ceko (penyiku) dengan menggabungkan pengukuran menggunakan jari dan lengan tangan, yaitu seukuran sasingku (satu depa) dan sacaka (satu jengkal).

Pada ukuran yang kurang lebih satu meter, metode yang digunakan ialah melentangkan satu bagian tangan dan melipat setengah bagian tangan yang lain. Posisi telapak tangan yang dilipat tepat didepan dada, istilah ukuran seperti ini dalam bahasa Bima biasa disebut salipa (satu lipatan). Metode pengukuran terpanjang pada masyarakat Bima menggunakan sandupa (satu meter). Pada pembuatan Uma Lengge yang menggunakan lipa (pengukuran melipat tangan) dan ndupa (bentangan tangan) dilakukan pada proses pembuatan ri'i (tiang), nggapin (pengapit), nggoren (balok penyangga), pangeren (balok penyeimbang tiang utama), panggalarin (balok pemisah kedua pasangan tiang), boko (balok tempat pengikat atap), dan talibawo (plafon). 
Adapun metode dari pengukuran diatas umumnya dipakai oleh orang dewasa, sedangkan hasil uku ando to ' $i$ (pengukuran anak-anak) bukan standar ukuran utama dalam penggunaan pengukuran pada bangunan tradisional Uma Lengge. Pada umumnya ukuran Uma Ngge'e (Rumah tempat tinggal) maupun Uma Lengge (Rumah Lumbung Padi) masyarakat Bima biasanya ditentukan oleh ukuran tangan dari pemiliknya sesuai intruksi oleh pengrajin dan kepala suku.

Selisih potongan dan ukuran bagian dari komponen-komponen bangunan ini memberikan variasi besar dan kecil, contoh yang sangat nampak dapat dicermati dari bentuk depan dan samping pada tiap bangunan Uma Lengge. Bagian depan Uma Lengge memiliki dua bentuk variasi yaitu prismasegitiga dan segitiga lancip, sedangkan pada bagian samping dari Uma Lengge memiliki dua variasi ukuran juga, antara lain merefleksikan bentuk prisma dengan ukuran lebar atas (talibawo) kurang lebih 3 meter dan bagian bawah (panggalari) ukurannya 3 meter. Selain itu, Uma Lengge memiliki bentuk trapesium dengan ukuran atas (talibawo) sepanjang 3 meter dan bagian bawah (panggalari) adalah 5 meter.

\section{Eksplorasi Geometri Bangun Datar pada Uma Lengge}

\section{Ceko}

Uma Lengge memiliki memiliki penyiku bangunan yang disebut dengan ceko. Ceko adalah sepasang penyiku yang berfungsi untuk memperkuat tiang-tiang utama. Adapun arsitektur ceko membentuk pola segitiga siku-siku. Untuk lebih jelas dapat dilihat pada gambar berikut.to
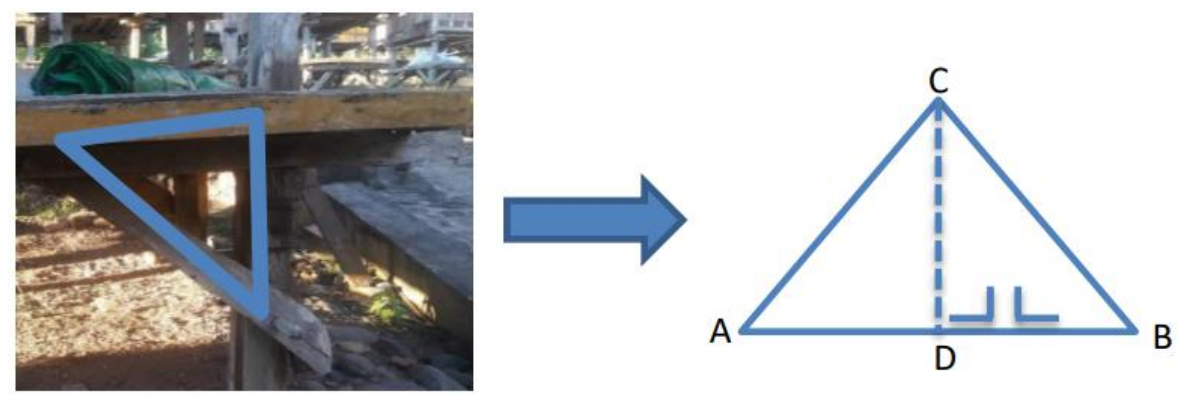

Gambar 2. Konsep dan Prinsip Segitiga pada Ceko

Berdasarkan gambar 2, penyiku dasar tiang Uma Lengge dibangun dengan bentuk Segitiga sikusiku sama kaki. Segitiga siku-siku merupakan sebuah segitiga yang memiliki satu sudutnya tepat sebesar $90^{\circ}$ (Wulandari, 2017). Jenis segitiga ini memiliki sisi yang berhadapan dengan sudut tegak lurus yang disebut hipotenusa atau sisi terpanjang pada segitiga siku-siku, dan sisi lainnya merupakan kaki dari segitiga. Berdasarkan pemodelan bentuk segitiga $A B C$, yang dibatasi oleh satu garis $D$ di atas, maka terdapat bentuk segitiga sama kaki dengan sifat-sifat yang dapat ditemukan, antara lain:

- Memiliki dua sisi sama panjang yaitu $A C=B C$

- Memiliki dua sudut yang sama besar yaitu $\mathrm{L}_{A}=\mathrm{L}_{B}=90^{\circ}$

- Memiliki satu sumbu simetri yaitu $C D$

- Memiliki dua sisi miring/hipotenusa yaitu $A C$ dan $B C$ 


\section{Lante}

Uma Lengge memiliki lantai yang dalam bahasa Bima disebut sebagai lante. Lantai yang dimaksud ialah lante yang terletak pada ro woha. Adapun arsitektur lante Uma Lengge membentuk pola persegi. Untuk lebih jelas dapat dilihat pada gambar berikut:
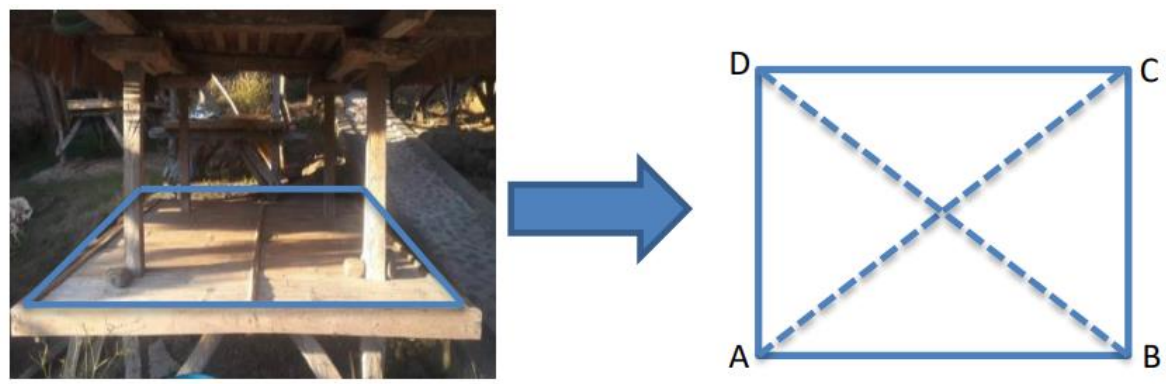

Gambar 3. Pola Persegi pada Lante

Berdasarkan gambar 3, pada setiap lantai Uma Lengge dibangun dengan bentuk persegi. Persegi merupakan bangun datar yang terdiri dari empat sisi sama panjang serta memiliki sudut tepat sebesar $90^{\circ}$ (Putra dkk., 2015). Berdasarkan pemodelan bentuk segiempat ABCD pada Uma Lengge, maka terdapat sifat-sifat yang ditemukan dalam lantai Uma Lengge, antara lain:

- Memiliki empat sisi sama panjang yaitu $A B=B C=C D=D A$

- Memiliki dua sudut yang sama besar yaitu ${ }^{\mathrm{L}} A=\mathrm{L}_{B}={ }^{\mathrm{L}} C={ }^{\mathrm{L}} D=90^{\circ}$

- Memiliki 4 simetri putar dan 4 simetri lipat.

\section{Kabu tadancai}

Dalam bahasa Bima kabu tadancai adalah tempat masuknya penghuni rumah, biasanya dibuat sesuai ukuran tinggi tubuh penghuninya. Bentuk kabu tadancai ada dua variasi, diantaranya ada yang dibuka keatas ada juga yang dibuka kesamping. Lebih jelas dapat dilihat pada gambar 3.
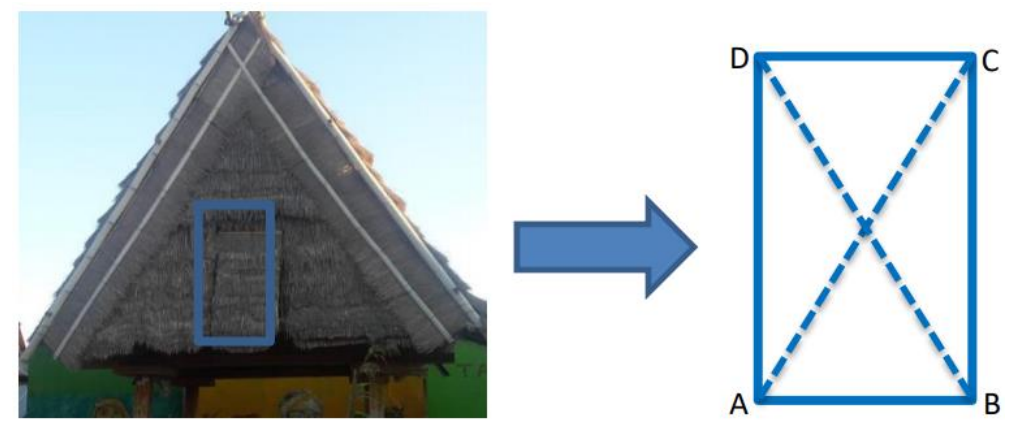

Gambar 4. Pola Persegi Panjang pada Kabu Tadancai

Berdasarkan gambar 4, dapat diketahui panjang dan tinggi kabu tadancai memiliki ukuran yang berbeda (Zahroh, 1985). Hal ini dikarenakan arsitektur kabu tadancai ditemukan sebuah bentuk persegi panjang. Adapun sifat-sifat persegi panjang yang dapat ditemukan adalah:

- Memiliki empat sisi yang tidak semuanya sama, yaitu $A B \neq B C, C D \neq D A, A B=C D, B C=D A$.

- Memiliki dua sudut yang sama besar yaitu ${ }^{\mathrm{L}} A=\mathrm{L}_{B}={ }^{\mathrm{L}} C={ }^{\mathrm{L}} D=90^{\circ}$.

- Memiliki 2 simetri putar dan 2 simetri lipat. 


\section{Eksplorasi Geometri Bangun Ruang pada Uma Lengge}

Atap

Atap Uma Lengge terbuat dari alang-alang atau bambu sirap yang biasa ditemukan di hutan. Masyarakat tradisional Bima menggunakan bahan dari alam, karena pada zaman dahulu belum ada bahan-bahan bangunan modern. Atap Uma Lengge tersebut dapat dilihat pada gambar di bawah ini.
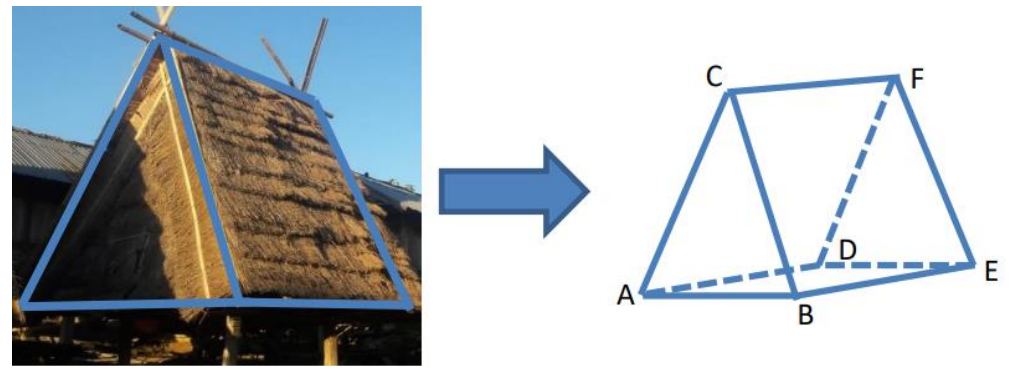

Gambar 5. Konsep dan Prinsip Prisma Segitiga pada Atap

Berdasarkan gambar 5, Atap Uma Lengge memiliki bentuk prisma segitiga yang dibangun pada ruang tiga dimensi, dimana dibatasi oleh alas dan tutupnya merefleksikan segitiga dan sisi-sisinya berbentuk persegi tegak (Putra dkk., 2015). Dari bentuk atap ini membentuk rumus volume dan luas permukaan prisma, yaitu:

-Volume, $V=$ Luas Alas $\times$ Tinggi

- Luas Permukaan, $L=(2 \times$ Luas alas $)+($ Keliling alas $\times$ tinggi $)$

\section{Ro woha}

Ro woha merupakan ruangan terbuka yang tersusun dari empat tiang utama yang biasanya dijadikan sebagai tempat beristirahat dan menerima tamu. Adapun gambar ro woha dapat dilihat sebagai berikut:
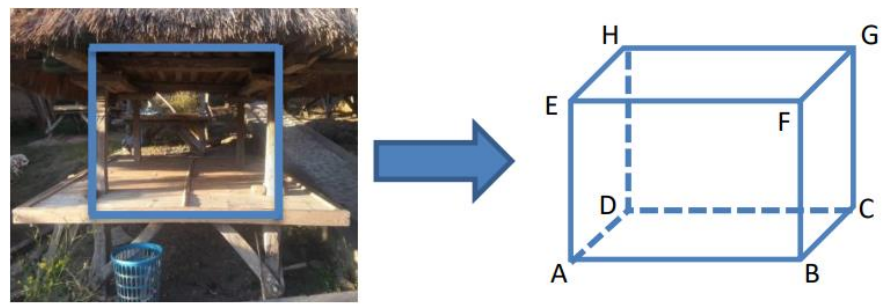

Gambar 6. Konsep dan Prinsip Kubus pada ro woha

Berdasarkan gambar 6, ro woha dibangun pada ruang tiga dimensi, dimana dibatasi oleh enam area sisi kongruen persegi. Kubus memiliki enam sisi, dua belas rusuk, dan delapan sudut (Wulandari, 2017). Berikut rumus dari volume dan luas permukaan kubus, yaitu:

- Formula untuk menghitung volume kubus yaitu, $\mathrm{V}=\mathrm{r}^{3}($ sisi $\times$ sisi $\times$ sisi $)$

- Luas permukaan $(\mathrm{L})=6 \times \mathrm{r}^{3}(\operatorname{sisi} \times \operatorname{sisi} \times$ sisi $)$

Nggore

Nggore adalah balok yang terletak di atas nggapi (pengapit tiang) yang memiliki ukuran dan jarak tertentu. Nggore berfungsi sebagai penyangka tempat duduk lante ro awa. Untuk lebih jelas dapat dilihat pada gambar di bawah ini: 

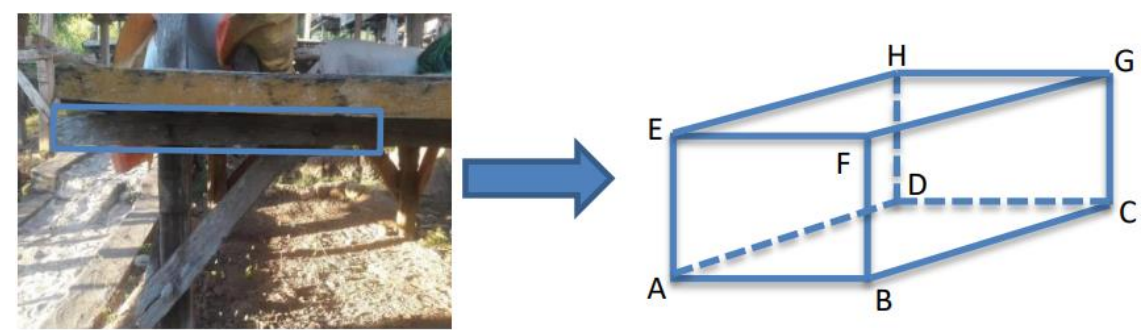

Gambar 7. Konsep dan Prinsip Balok dalam nggore

Berdasarkan gambar 7, dapat diketahui bahwa pelapis antara tiang dasar dan ruang bawah Uma Lengge dibangun pada ruang tiga dimensi, yaitu sepasang balok yang dibentuk oleh tiga pasang persegi dan persegi panjang yang terdiri dari dua belas rusuk yang tidak sama panjang (Putra dkk., 2015). Berikut rumus dari volume, keliling, dan luas permukaan balok, yaitu:

- Volume, $V=p \times l \times t$

- Keliling, $K=4(p+l+t)$

\section{Pelampu}

Uma Lengge memiliki arsitektur yang unik pada bagian atas bangunan karena terdapat potongan kayu penyambung antara ruangan bawah dengan atap yang disebut pelampu. Adapun pelampu dapat dilihat pada gambar berikut:
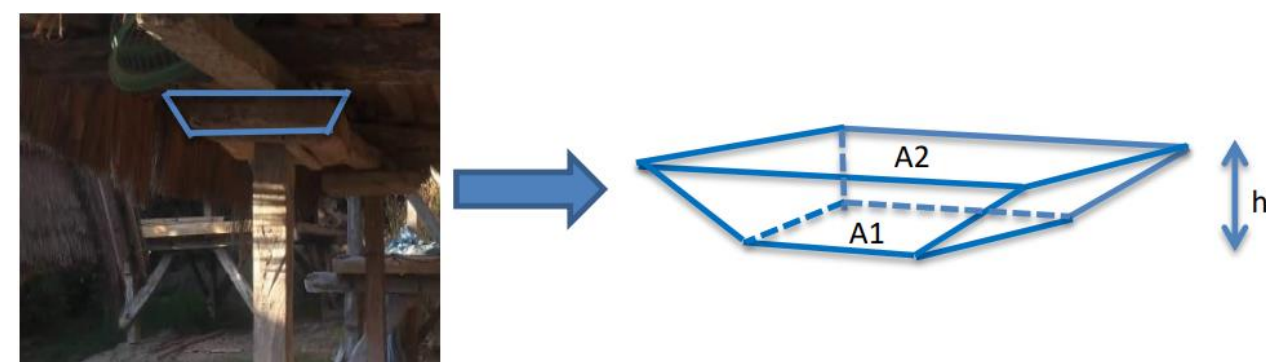

Gambar 8. Konsep frustum piramida pada pelampu

Berdasarkan gambar 8, terlihat pada atap Uma Lengge tedapat sebuah potongan kayu yang berfungsi sebagai penghalang tikus memasuki lumbung persediaan makanan atau biasa disebut pelaтри. Pelaтри berbentuk frustum piramida yang diletakkan terbalik dengan arsitektur berbentuk bangun ruang tiga dimensi yang merupakan perpotongan kerucut atau limas yang berada pada dua bidang sejajar. Berikut adalah rumus volume frustum, yaitu: $V=h / 3[A 1+A 2+\sqrt{A 1 \cdot A 2}]$

\section{KESIMPULAN}

Berdasarkan hasil eksplorasi terhadap bangunan Uma Lengge, dapat disimpulkan bahwa metode pengukuran yang digunakan masyarakat tradisional Bima sangat beragam. Dari ukuran yang paling terkecil atau terpendek hingga terbesar atau terpanjang. Ukuran terkecil dimulai dari menggunakan jari, sakimi (kepalan tangan), pengukuran sasingku (satu depa) yang dilakukan menggunakan siku, dan pada ukuran yang lebih satu meter dilakukan dengan melentangkan satu bagian tangan dan melipat setengah 
bagian tangan yang lain. Selain itu, pada rancang bangunan Uma Lengge terdapat konsep geometri bangun datar dan bangun ruang. Adapun konsep bangun datar pada bangunan Uma Lengge, antara lain konsep dan prinsip segitiga pada ceko, pola persegi pada lante, dan pola persegi panjang pada kabu tadancai. Selanjutnya konsep-konsep bangun ruang pada Uma Lengge, yaitu konsep dan prinsip prisma segitiga pada atap, konsep dan prinsip kubus pada ro woha, konsep dan prinsip balok dalam nggore, dan konsep frustum piramida pada pelampu.

\section{REFERENSI}

Asnawati, S., K.D., I. L., \& Muhtarulloh, F. (2015). Penerapan Pembelajaran Inkuiri Dengan Etnomatematik Pada Materi Bidang Datar Terhadap Kemampuan Pemahaman Matematis Siswa. Euclid, 2(2), 275-295. https://doi.org/10.33603/e.v2i2.363

D'Ambrosio. (1985). Ethnomathematics and its place in the history and pedagogy of mathematics. For the Learning of Mathematics.

D Herawaty, W Widada, T Novita, L Waroka, and A. N. M. T. L. (2018). Students' Metacognition on Mathematical Problem Solving Through Ethnomathematics in Rejang, Indonesia.

Dewi Murniati, L., Candisa Made, I., \& Kirna Made, I. (2013). Pengembangan perangkat pembelajaran matematika realistik untuk meningkatkan kemampuan pemecahan masalah siswa smp. Jurnal Pendidikan Dan Pengajaran, 46(2), 114-124.

Elly Susanti, Nur Wiji Sholikin, Marhayati, T. (2020). Designing Culturally-rich Local Games for Mathematics Learning. 13(1), 49-60.

Funan, F. X., Mamoh, O., Studi, P., Matematika, P., Timor, U., Barat, K. I., \& Geometri, K. (2019). EKSPLORASI ETNOMATEMATIKA UEM LE' U INSANA DALAM. 1(1), 63-75.

I Gusti Putu Suharta, I. G. P. S. and I. W. P. A. (2017). Ethnomathematics of Balinese Traditional Houses. 3(4), 47-56.

J B Darmayasa, Wahyudin, T. M. (2018). Ethnomathematics: The use of multiple linier regression $Y=b 1 X 1+b 2 X 2+e$ in traditional house construction Saka Roras in Songan Village.

Jayanti, T. D., \& Puspasari, R. (2020). Eksplorasi etnomatematika pada Candi Sanggrahan Tulungagung. 6(2), 53-66.

Mulbar, U. (2012). Kata kunci: Desain Pembelajaran Matematika, Sistem Sosial Masyarakat. Pengembangan Desain Pembelajaran Matematika dengan Memanfaatkan Sistem Sosial Masyarakat, 7(1), 1-6.

Putra, A. S., Santoso, L. W., \& Palit, H. N. (2015). Pembelajaran Interaktif Bangun Ruang dan Bangun Datar Untuk Sekolah Menengah Pertama ( SMP ) Berbasis Android.

Putri, L. I. (2017). Eksplorasi Etnomatematika Kesenian Rebana Sebagai Sumber Belajar Matematika pada Jenjang MI. Jurnal Ilmiah “PENDIDIKAN DASAR,” IV(1), 21-31.

Richardo, R. (2017). Peran Ethnomatematika Dalam Penerapan Pembelajaran Matematika Pada $\begin{array}{llllll}\text { Kurikulum 2013. LITERASI (Jurnal Ilmu Pendidikan), } & \text { 7(2), } 118 .\end{array}$ https://doi.org/10.21927/literasi.2016.7(2).118-125 
Samo, D. D. (2017). Kemampuan Pemecahan Masalah Mahasiswa Tahun Pertama pada Masalah Geometri Konteks Budaya Problem Solving Ability of First Year University Student in Cultural Context Geometry Problem. 4(2), 141-152.

Sandhi, N. S. A., Trapsilasiwi, D., Yudianto, E., Suharto, \& Sugiarti, T. (2018). Etnomatematika Pola Tarian Jejer Jaran Dawuk Banyuwangi sebagai Inspirasi Pengembangan Paket Tes Geometri. Kadikma, 9(3), 160-170.

Sudirman, Rosyadi, \& Lestari, W. D. (2017). Penggunaan etnomatematika pada karya seni batik Indramayu dalam pembelajaran geometri transformasi. Pedagogy, 2(1), 74-85.

Sulistyani, A. P., Windasari, V., Rodiyah, I. W., \& Muliawati, N. E. (2019). Eksplorasi Etnomatematika Rumah Adat Joglo Tulungagung. 7(1), 22-28.

Tlonaen, M. A., \& Deda, Y. N. (2021). Exploration Ethnomathematics on Traditional House Ume Kbubu in North Central Timor Districts. https://doi.org/10.1088/1742-6596/1776/1/012016

Ulum, B., Budiarto, M. T., \& Ekawati, R. (2018). Etnomatematika Pasuruan: Eksplorasi Geometri Untuk Sekolah Dasar Pada Motif Batik Pasedahan Suropati Mahasiswa Program Pascasarjana, Prodi Pendidikan Dasar, Universitas Negeri Surabaya, Dosen Pascasarjana, Prodi Pendidikan dasar, Universitas Negeri .4(2).

Widada, W., Herawaty, D., Falaq, A., Anggoro, D., Yudha, A., \& Hayati, M. K. (2019). Ethnomathematics and Outdoor Learning to Improve Problem Solving Ability. 295(ICETeP 2018), $13-16$.

Wulandari, C. (2017). Menanamkan Konsep Bentuk Geometri (Bangun Datar). Jurnal Pengabdian Masyarakat Ipteks, 3(1), 1-8.

Yuningsih, N., Nursuprianah, I., \& Manfaat, B. (2021). Eksplorasi Etnomatematika pada Rancang Bangun Rumah Adat Lengkong. 3(1), 1-13.

Zahroh, U. (1985). Penerapan Pembelajaran Berbasis Etnomatematika. 1-17. http://blog.iaintulungagung.ac.id/red-c/wp-content/uploads/sites/109/2018/04/RED-C_Penerapan-

Pembelajaran-Etnomatematika.pdf 